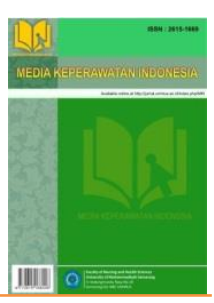

Research article

\title{
The Influence of Time-Out Applied by Parents toward Students' Intensity in Playing Game
}

\author{
Muhamad Aenul Yaqin', MariyamMariyam² \\ 1,2 Program Studi Ilmu Keperawatan, Fakultas Ilmu Keperawatan dan Kesehatan, Universitas Muhammadiyah \\ Semarang, Indonesia
}

\section{Article Info}

Article History:

Accepted June 24th, 2020

\section{Keywords:}

Intensity playing game,

Time-out

\begin{abstract}
The impact of online game dependence includes aggressive behavior, lack of respect for other people, and threatening persecution. Playing games will not be controlled if parents do not supervise or set limits. Time out is expected to reduce the intensity of playing online games in school-age children. This study aims to determine the effect of time out by parents on the intensity of playing games in school-age children. The design of this study was an experiment with one group pre-test post-test. Respondents were 50 parents with school-age children who had moderate and highintensity games. Time out interventions (isolation time out) are carried out by parents with a time adjusting the child's age, carried out for 5 days. The intensity of gameplay describes the duration of gameplay in a day, the classification is low, moderate, and high. The results showed that the intensity of playing games before being given time out was mostly in high classification (54\%). Statistical test results indicate that there is a time out by parents of the intensity of playing games in school-age children ( $p=$ $0.0001)$.
\end{abstract}

\section{PENDAHULUAN}

Game atau sering disebut Games adalah merupakan suatu alat yang sangat berpengaruh bagi kehidupan dan perkembangan teknologi yang ada dan tidak terpisahkan bagi kehiduan seorang anak (Ridoi, 2018). Hasil survey penetrasi pengguna internet pada tahun 2018 di Indonesia meningkat menjadi 143,26 juta jiwa atau setara 54,7 persen (APJII, 2018). Pada tahun 2018 jumlah gamer di Indonesia meningkat menjadi 34 juta orang dari jumlah tersebut 19,9 juta diantaranya gamer online berbayar (Rachmawati, $\underline{\text { 2018). }}$.

Efek dari konsumsi permainan game dan game online adalah pola perilaku permainan (digital-gaming atau video gaming) gangguan ini dinamai gaming disorder, pengidap gaming akan bermain secara berlebihan baik lama bermain atau intensitas bermain game (WHO, 2019). Efek lain dari kebergantungan bermain game adalah perilaku agresi, kurang menghargai orang lain, penganiayaan dengan cara mengancam, dan kecanduan dengan game

Corresponding author:

Muhamad Aenul Yaqin

aenulyaqin1@gmail.com

Media Keperawatan Indonesia, Vol 3 No 2, Juni 2020

e-ISSN: 2615-1669

ISSN: 2722-2802

DOI: https://doi.org/10.26714/mki.3.2.2020.70-74 
(Trihadnanto, A., \& Agency, 2011). Kondisi akan berbeda apabila anak dalam pengawasan orang tua atau memberikan batasan waktu dan arahan dalam bermain game offline maupun online yang sesuai umur anak.

Meminta anak untuk berhenti bermain games merupakan hal yang tidak mudah, orang tua membutuhkan cara yang tepat, tidak menyalahkan anak. Time out merupakan suatu tindakan hukuman kepada anak yang tidak menggunakan kekerasan fisik, melainkan agar anak mengintropeksi diri akan kesalahan yang diperbuat atau melanggar aturan (Wong, $\underline{2015})$. Time out adalah menghentikan kegiatan anak dan meminta untuk diam di tempat yang aman merupakan strategi pendisiplinan yang sangat baik untuk anak yang masih kecil, ketika ditempat yang tidak terstimulasi dan terisolasi anak menjadi bosan dan pada akhirnya setuju untuk berperilaku yang sesuai.

Penelitian ini bertujuan untuk mengetahui pengaruh time out yang diberikan oleh orang tua terhadap intensitas bermain game pada anak usia sekolah.

\section{METODE}

Desain penelitian yang digunakan eksperiment dengan rancangan one - group pre test - post test design ( Sugiyono, 2016). Penelitian ini mengukur intensitas bermain game pada anak usia sekolah sebelum diberikan time out dan sesudah diberikan time out oleh orang tua.

Populasi dalam penelitian ini keseluruhan orang tua anak dengan intensitas bermain game dalam kategori sedang dan tinggi di kelas 3 B dan 5 A SD Negeri Luwungragi 01 sebanyak 50 siswa-siswi. Metode pengambilan sampel yang digunakan adalah probability sampling dengan memberikan peluang yang sama dalam setiap unsur anggota populasi untuk dijadikan sampel. Teknik pengambilan sampel dalam penelitian ini adalah total sampling, jumlah sampel penelitian ini sejumlah 50 responden. Kriteria inklusi sampel antara lain orang tua dengan anak yang intensitas bermain game dengan kategori sedang dan tinggi.

Intensitas bermain game dikaji sebelum dilakukan intervensi time out dan setelah dilakukan intervensi time out selama 5 hari dilakukan pengkajian intensitas bermain game kembali. Intensitas bermain game diukur dengan menggunakan lembar observasi waktu/intensitas anak menggunakan gadget untuk bermain game dalam sehari, dikategorikan rendah $\quad<30$ menit dengan durasi maksimal 2 kali pemakaian), sedang (40-60 menit dengan durasi 2-3 kali pemakaian), dan kategori tinggi (lebih dari 60 menit per hari secara terus menerus atau lebih 120 menit).

Orang tua melakukan pemantauan di rumah tentang intensitas bermain game, orang tua menegur anak dan memberikan penjelasan maksud dari tindakan time out dan memastikan anak memahami. Time out oleh orang tua dilakukan dengan cara orang tua menempatkan anak disuatu tempat dan anak tidak melakukan kegiatan apapun. Orang tua memberikan time out dengan waktu menyesuaikan usia anak (missal anak usia 4 tahun diberikan 4 menit). Orang tua tetap mengawasi anak dan diam menunggu sampai waktu time out selesai. Pada tahap terakhir orang tua mencairkan suasana dan bersikap seperti biasa setelah selesai pemberian time out.

Analisis pengaruh time out yang diberikan oleh orang tua terhadap intensitas bermain game menggunakan uji Wilcoxon karena data berdistribusi tidak normal.

Penelitian ini menerapkan etika penelitian antara lain dengan memberikan informed concent, merahasiakan nama responden dan telah lolos ethical clearance dengan nomor 185/KEPK-FKM/UNIMUS/2019. 
HASIL

Penelitian ini dilakukan pada 50 responden yang intensitas bermain game kategori sedang dan tinggi. Peneliti meminta persetujuan kepada pihak sekolah dan mengundang orang tua ke Sekolah dan diberikan penjelasan penelitian serta penjelasan bagaimana pelaksanaan time out.

Hasil penelitian ini menunjukkan jenis kelamin anak sebagian besar perempuan. Pendidikan ibu didominasi pendidikan SD.

Tabel 1 Karakteristik Responden

\begin{tabular}{lcc}
\multicolumn{3}{c}{ Karakteristik Responden } \\
\hline \multicolumn{1}{c}{ Indikator } & $\mathrm{f}$ & $\%$ \\
\hline Jenis kelamin anak & & \\
$\quad$ Perempuan & 27 & 54.0 \\
Laki - laki & 23 & 46.0 \\
\hline Pendidikan orang tua & & \\
Tidak lulus SD & 7 & 14.0 \\
SD & 15 & 30.0 \\
SMP & 12 & 24.0 \\
SMA & 8 & 16.0 \\
D3 / S1 & 7 & 14.0 \\
S2 & 1 & 2.0 \\
\hline Pekerjaan orang tua & & \\
Tani & 16 & 32.0 \\
Swasta & 9 & 18.0 \\
PNS & 6 & 12.0 \\
Lain - lain & 19 & 38.0 \\
\hline
\end{tabular}

Intensitas bermain game anak dikategorikan menjadi 3 kategori, yaitu rendah ( $<30$ menit), sedang (40-60 meit), dan tinggi ( $>60$ menit). Hasil penelitian menunjukkan bahwa intensitas bermain game anak sebelum dilakukan intervensi berada dalam kategori sedang (46\%) dan tinggi (54\%). Sedangkan setelah dilakukan intervensi intensitas bermain game anak mengalami penurunan dengan proporsi kategori rendah (27\%), sedang (22\%) dan tinggi $(2 \%)$.

Hasil penelitian menunjukkan bahwa terdapat perbedaan yang signifikan antara rerata intensitas bermain game sebelum dengan setelah pemberian time out $(\mathrm{p}=0,0001)$. Pemberian time out mampu menurunkan intensitas bermain game pada anak usia sekolah.
Tabel 2

Perbedaan Intensitas Bermain Game Sebelum dan sesudah Intervensi

\begin{tabular}{lccc}
\hline \multicolumn{1}{c}{ Indikator } & $\begin{array}{c}\text { Sebelum } \\
\text { intervensi }\end{array}$ & $\begin{array}{c}\text { Setelah } \\
\text { intervensi }\end{array}$ & $\mathrm{p}$ \\
\hline $\begin{array}{l}\text { Rerata } \\
\text { intensitas } \\
\text { bermain game } \\
\text { anak }\end{array}$ & 60 & & \\
\hline *Wilcoxon-test & & $25(7.63)$ & $0.0001^{*}$ \\
& & & \\
\end{tabular}

\section{PEMBAHASAN}

Bedasarkan hasil penelitian rerata intensitas bermain game anak usia sekolah sebelum dilakukan intervensi adalah 60 menit atau dalam kategori tinggi. Klasifikasi intensitas antara lain kategori rendah apabila bermain game $<30$ menit/ hari, kategori sedang apabila durasi antara 40-60 menit dan kategori tinggi apabila durasi lebih dari 60 menit/hari. Intensitas bermain game erat kaitannya dengan adanya factor tersedianya fasilitas bermain game di rumah, pengaruh lingkungan dan adanya keingintahuan tentang jenis game dan keinginan yang besar untuk memainkannya (Syahran, 2015).

Pada penelitian ini sebelum dilakukan intervensi orang tua mengetahui anaknya bermain game, sebagian orang tua menyampaikan suka memukul atau membentak anak karena sering bermain game, orang tua juga memarahi anak supaya berhenti bermain game. Intensitas bermain game pada anak perlu mendapat perhatian khususnya dari orang tua. Dampak negatif dari intensitas bermain game meliputi kurangnya tidur, hidup kotor, isolasi diri, depresi, stress, arthritis dan carpal tunnel syndrome, makan kurang sehat, perilaku agresif, gaya hidup buruk, dan berbohong (Ridoi, 2018).

Semakin tinggi intensitas bermain game online semakin rendah pula prestasi belajar matematika anak usia sekolah (Marlina, 2014). Hasil penelitian ini sesuai dengan penelitian Putra \& Sanubari yang menunjukkan terdapat anak bermain game dengan durasi > 3 jam per hari, dengan 
durasi > 21 jam perminggu, sehingga dikatakan anak - anak kecanduan bermain game (Manggena, Putra, \& Sanubari, 2017).

Berdasarkan hasil penelitian ini menunjukkan adanya perubahan intensitas bermain game sesudah diberikan time out oleh orang tua. Hasil ini sesuai dengan hasil penelitian sebelumnya yang menyampaikan bahwa kegiatan time out dalam menstimulasi sikap disiplin anak pra sekolah (Puspitasari. C. A. \& Kristanto, 2016). Pemberian time out dapat mengurangi perilaku agresif pada anak (Aulia. H., 2015).

Penanganan kepada anak dengan perilaku yang tidak sesuai harus dilakukan dengan tepat (Cooper, John, Timothy, 2007). Pemberian time out diharapkan menjadi intervensi yang tepat. Time out adalah suatu cara untuk menghilangkan prilaku negatif dengan cara memberikan waktu kepada anak dengan berpikir dengan tenang tentang apa yang sudah dilakukan. Time out adalah dilakukan dengan membiarkan anak di suatu ruangan yang tenang, time outsangat berguna bagi anak yang berusia 3-5 tahun. Prosedur ini (time out) efektif untuk menurunkan perilaku yang bermasalah atau perilaku negative (Miltenberger, 2004).

Pada penelitian ini time out yang diberikan adalah isolationary time out anak ditempatkan di ruang terpisah yang sebelumnya menunjukkan perilaku bermain game yang berlebihan. Menurut analisis peneliti time out bisa sangat bermanfaat bagi seluruh orang tua untuk menghentikan perilaku negatif anak yaitu bermain game yang berlebihan, karena teknik ini tidak mempunyai efek samping, tidak menggunakan fisik maupun verbal. Orang tua menyuruh anak berdiam di tempat yang sudah ditentukan tidak diajak berbicara dan menyingkirkan mainan yang didekatnya. Saat time out ini anak mengintropeksi diri akan kesalahan yang sudah dilakukan. Pada 5 hari setelah dilakukan pemberian time out menunjukkan intensitas bermain game anak berkurang. Berdasarkan hasil penelitian ini orang tua bisa melakukan time out pada anak yang intensitas bermain game dalam kategori sedang atau tinggi

\section{SIMPULAN}

Intervensi time-out yang dilakukan oleh orang tua mampu menurunkan intensitas main game anak usia sekolah.

\section{UCAPAN TERIMAKASIH}

Penulis ingin mengucapkan terima kasih kepada semua responden dalam penelitian ini.

\section{REFERENSI}

APJII. (2018). Cerita Dibalik Kesuksesan Pemerintah Tarik Pajak Google. https://apjii.or.id/downfile/file/BULETINAPJI IEDISI22Maret2018.pdf.

Aulia. H. (2015). Reducing Aggressive Behavior X Through Deaf Child Allowance Shortly Elimination Procedure (Time-Out) (Single Subject Design Class II.B in SLB Muhammadiyah Pauh IX Padang). E-Jupekhu, Vol 4 No 1.

Cooper, John, O, Timothy E Heron, W. L. H. (2007). Applied Behavior Analysis. New Jersey: Pearson.

Manggena, T. F., Putra, K. P., \& Sanubari, T. P. E. (2017). Pengaruh Intensitas Bermain Game Terhadap Tingkat Kognitif (Kecerdasan Logika - Matematika) Usia 8 - 9 Tahun. Satya Widya, $33(2)$.

https://doi.org/https://doi.org/10.24246/j.s w.2017.v33.i2.p146-153

Marlina, N. P. (2014). Hubungan bermain game online dengan prestasi belajar matematika anak usia sekolah kelas $\mathrm{V}$ di sekolah dasar Saraswati 1 Denpasar. E-Jurnal Universitas Udayana. $\quad$ Retrieved from https://ojs.unud.ac.id/index.php/index/articl e/view/10787

Miltenberger, R. G. (2004). Behavior Modification: Principles and Procedures. USA: Wadsworth.

Puspitasari. C. A., \& Kristanto, A. (2016). Kegiatan Time Out Di Tk Aisiyah Bustanul Athfal 47 Surabaya. PAUD Teratai, 5(1). Retrieved from https://jurnalmahasiswa.unesa.ac.id/index.ph p/paud-teratai/article/view/14214

Rachmawati. (2018). Gamer Indonesia Diprediksi 
capai 34 juta orang. http://www.pikiranrakyat.com/ekonomi/2018/08/06/gamerindonesia-diprediksi-capai-34-juta-orang428379.

Ridoi. (2018). Cara Mudah membuat Game Edukasi Dengan Contruct. Malang: Maskha.

Sugiyono. (2016). Metode Penelitian Kuantitatif, Kualitatifdan $R$ \& D. Bandung: Alfabeta.

Syahran. (2015). Ketergantungan online game dan penanganannya. Jurnal Psikologi Pendidikan \&
Konseling, 1(Juni), 84-92.

Trihadnanto, A., \& Agency, B. (2011). Optimalkan Potensi Anak Dengan Game (PT Elex Me). Jakarta.

WHO. (2018). http://www.pikiranrakyat.com/ekonomi/2018/08/06/gamerindonesia-diprediksi-capai-34-juta-orang428379.

Wong. (2009). Buku Ajar keperawatan Pediatrik Wong ed.6.vol1. Jakarta: Buku Kedokteran EGC. 